\title{
CORRELATION AND REGRESSION STUDIES OF RICE VARIETIES INFLUENCED BY COMBINATION OF PLANT DENSITY AND FERTILIZER LEVELS
}

\author{
O. SAMPATH, A. SRINIVAS, K. AVIL KUMAR \& T. RAMPRAKASH \\ Department of Agronomy, College of Agriculture, Prof. Jayashankar Telangana State
}

Agricultural University, Rajendranagar, Hyderabad, India

A field experiment was conducted on a sandy clay loam soil at the college farm of Professor Jayashankar Telangana State Agricultural University, Rajendranagar, Hyderabad, Rajendranagar, Hyderabad, Telangana during the kharif seasons of 2014 and 2015, to study the correlation and regression analysis of rice varieties as influenced by combination of plant densities and fertilizers under late sown condition. Grain yield was found to be significantly and positively correlated with number of tillers $m^{-2}(r=0.93 * * *)$, leaf area index $(r=0.83 * * *)$, dry matter production $(r=0.99 * * *)$, panicle number $(r=0.95 * * *)$. Similarly regression of grain yield on the number of tillers $m^{-2}\left(R^{2}=0.873 * *\right)$, LAI $\left(R^{2}=0.703 * *\right)$, total dry matter production $\left(R^{2}=0.997 * *\right)$, number of panicles $m^{-2}\left(R^{2}=0.908 * *\right)$, nitrogen uptake $\left(\boldsymbol{R}^{2}=0.990^{* *}\right)$, phosphorus uptake $\left(\boldsymbol{R}^{2}=0.950 * *\right)$ and potassium uptake $\left(\boldsymbol{R}^{2}=0.998^{* *}\right)$ showed a significant and positively associated between them. The dependence of the dry matter was found to be significantly and positively correlated with number of tillers $m^{-2}(r=0.94 * * *)$, leaf area index $(r=0.83 * * *) N$ uptake $(r=0.99 * * *), P$ uptake (r $\left.=0.97 * * *\right)$ and $K$ uptake $(r=0.99 * * *)$ showed significant positive correlation with dry matter of rice. Regression equation obtained in the study revealed LAI, tillers $m^{-2}, N, P, K$ uptake and dry matter of rice at maturity accounted for $68 \%, 88 \%, 98 \%, 94 \%$ and 99\% of total variation in dry matter production of rice.
\end{abstract}

KEYWORDS: Mohanty, Faostat Database, Singh \& Namdeo

Received: Apr 13, 2017; Accepted: May 10, 2017; Published: May 25, 2017; Paper Id.: IJASRJUN201729

\section{INTRODUCTION}

Rice (Oryza sativa (L.)) is one of the most important staple food crops in the world. However, more than 90 per cent of rice is consumed in Asia, where it is a staple food for a majority of the population, including the 560 million hungry people in the region (Mohanty, 2013). In Asia, more than two billion people are getting 60-70 per cent of their energy requirement from rice and its derived products. Among the rice growing countries, India has the largest area (42.27 $\mathrm{m} \mathrm{ha})$ and it is the second largest producer (105.24 $\mathrm{m} \mathrm{t}$ ) of rice next to China (144 m t). With an average productivity of $2.49 \mathrm{t} \mathrm{ha}^{-1}$, though increasing marginally, but is still well below the world's average yield of $4.36 \mathrm{t} \mathrm{ha}^{-1}$ (FAOSTAT Database, 2014). At the current population growth rate $(1.5 \%)$, the rice requirement of India by 2025 would be around $125 \mathrm{~m} \mathrm{t}$ (Kumar et al., 2009). The importance of continuing to develop new rice varieties to guarantee India's food security and support the region's economic development needs no special emphasis. Varieties play a vital role in maximizing of yield by improving the input use efficiency. The adverse effect of late transplanting can also be minimized by selecting a suitable cultivar as the magnitude of yield reduction varies with the rice cultivars. Plant population exerts a strong influence on the rice growth and grain yield, because of its competitive effects, both on the vegetative and reproductive development. Optimum plant spacing ensures plants to grow properly both in their aerial and underground parts through utilization of solar radiation and nutrients, therefore proper 
manipulation of planting density may lead to increase in the economic yield of transplanted rice. Balanced fertilization right from the very beginning of crop growth is utmost essential to achieve better harvest of the crop (Singh and Namdeo, 2004). Usually, rice yield declines when transplanting is delayed beyond the optimum time (Ologunde, 1987). The optimal date of transplanting of any field crop depends on the environmental conditions required for good growth and development. The farmer, therefore, seeks to manage the relationship between the crop and its environment in order to optimize growth and yield.

The present study is proposed to study growth parameters of rice varieties as influenced by combination of plant density and fertilizer levels under late sown conditions.

\section{MATERIAL AND METHODS}

A field experiment was conducted during the kharif season of 2014 and 2015 at the Agricultural College Farm, Rajendranagar, Hyderabad. The experimental site was geographically situated at an altitude of $542.6 \mathrm{~m}$ above mean sea level, on $17^{0} 19^{1} \mathrm{~N}$ latitude and $78^{0} 24^{1} \mathrm{E}$ longitudes. It comes under the Southern Telangana zone of Telangana. The soil was sandy clay loam in texture, neutral in reaction $(\mathrm{pH} \mathrm{7.2)} \mathrm{with} 0.49 \%$ of organic matter, with low available nitrogen $\left(180.8 \mathrm{~kg} \mathrm{ha}^{-1}\right)$, high available phosphorus $\left(38.6 \mathrm{~kg} \mathrm{ha}^{-1}\right)$ and potassium $\left(312 \mathrm{~kg} \mathrm{ha}^{-1}\right)$.

The experiments were laid out in a split plot design with three replications. Three varieties MTU 1010, Rajendra and Pradyumna as main plot treatments, three plant densities $\left(\mathrm{P}_{1}: 20\right.$ x $20 \mathrm{~cm}, \mathrm{P}_{2:}: 15$ x $15 \mathrm{~cm}$ and $\left.\mathrm{P}_{3:} 15 \mathrm{x} 10 \mathrm{~cm}\right)$, three fertilizer levels $\left(\mathrm{F}_{1:} 111-32-45, \mathrm{~F}_{2:}\right.$ 153-59-68 and $\mathrm{F}_{3:}$ 195-86-90) as sub plot treatments.

The fertilizer levels111-32-45 $\mathrm{kg}$ NPK ha $^{-1,} 153-59-68 \mathrm{~kg} \mathrm{NPK} \mathrm{ha}^{-1}$ and 195-86-90kg NPK ha ${ }^{-1}$ were applied at 50 percent $\mathrm{N}$, full dose of $\mathrm{P}$ and 50 percent $\mathrm{K}$ at the time of transplanting. Nitrogen was applied as per the treatments in 3 split doses as basal $50 \%$ and at active tillering and panicle initiation stages $25 \%$ each. The remaining half of potassium was applied at panicle initiation stage.

\section{REGRESSION AND CORRELATION STUDIES}

\section{Regression of Rice Yield on Growth and Yield Components}

Crop yield (dependent variable) was assumed as a function of various growth traits, yield components and nutrient uptake (independent variable) and the following straight line model was established by least square technique (Gomez and Gomez, 1984) as follows:

$\mathrm{Y}=\mathrm{a}+\mathrm{b}[\mathrm{x}]$

Where,

$\mathrm{Y}=$ Grain yield of rice

$\mathrm{a}=\mathrm{Y}-\mathrm{axis}$ intercept

$b=$ Regression coefficient

$\mathrm{x}=$ growth and yield components

\section{Correlation Studies}

Correlation matrix between grain yield of rice $\left(\mathrm{kg} \mathrm{ha}^{-1}\right)$ and various growth and yield parameters viz., plant height, 
number of tillers $\mathrm{m}^{-2}$, leaf area index, dry matter production, number of panicles $\mathrm{m}^{-2}$, number of filling grains panicle ${ }^{-1}$, sterility $\%$, test weight, straw yield and NPK uptake were established by adopting the least square technique.

\section{RESULTS AND DISCUSSIONS}

\section{Correlation and Regression Analysis}

Correlations between Growth Parameters and Grain Yield

Correlation studies between growth parameters viz. Pooled tillers $\mathrm{m}^{-2}, \mathrm{LAI}$ and DM at maturity and grain yield of rice were carried out and presented in Table 1.

The dependence of the grain yield was found to be significantly and positively correlated with number of tillers $\mathrm{m}$ ${ }^{2}\left(\mathrm{r}=0.96^{* *}\right)$, leaf area index $\left(\mathrm{r}=0.83^{* *}\right)$ and dry matter production $\left(\mathrm{r}=0.99^{* *}\right)$ observed in the present experiment (Table 1).

\section{Correlation between Yield Parameters and Grain Yield}

The correlation between yield attributes and grain yield of rice revealed that panicles $\mathrm{m}^{-2}\left(\mathrm{r}=0.95^{* * *}\right)$, panicle length $\left(r=0.44^{*}\right)$ and test weight $\left(r=0.43^{*}\right)$ showed significant positive correlation with grain yield of rice (Table 1). The sterility percentage showed negative correlation with the grain yield of rice $(r=-0.24)$. These significant associations were consistent with earlier findings of rice (Shahidullah et al., 2009)

\section{Correlation between Nutrient Uptake and Grain Yield}

The correlation between $\mathrm{N}, \mathrm{P}, \mathrm{K}$ uptake and grain yield of rice revealed that $\mathrm{N}$ uptake $\left(\mathrm{r}=0.99^{* * *}\right)$, P uptake $\left(\mathrm{r}=0.97^{* * *}\right)$ and $\mathrm{K}$ uptake $\left(\mathrm{r}=0.99^{* * *}\right)$ showed significant positive correlation with grain yield of rice (Table 1$)$.

\section{Correlations between Growth Parameters, Nutrient Uptake and Dry Matter Production}

Correlation studies between growth parameters viz. Tillers $\mathrm{m}^{-2}$, LAI and N, P, K uptake at maturity and dry matter production of rice were carried out and presented in Table 1.

The dependence of the dry matter production was found to be significantly and positively correlated with number of tillers $\mathrm{m}^{-2}\left(\mathrm{r}=0.94^{* * *}\right)$, leaf area index $\left(\mathrm{r}=0.83^{* * *}\right)$, $\mathrm{N}$ uptake $\left(\mathrm{r}=0.99^{* * *}\right)$, $\mathrm{P}$ uptake $\left(\mathrm{r}=0.97^{* * *}\right)$ and $\mathrm{K}$ uptake $(\mathrm{r}=$ $0.99^{* * *}$ ) showed significant positive correlation with dry matter production of rice (Table 1).

\section{REGRESSION STUDIES}

\section{Regression between Growth Parameters and Yield}

Regression equation obtained in the study revealed that, tillers $\mathrm{m}^{-2}$, LAI and DM at maturity accounted for $87 \%$, $70 \%$ and $99 \%$ of total variation in grain yield of rice (Figure 4.10)

\section{Regression between Yield Parameters and Grain Yield}

Regression equation obtained in the study revealed panicle length, productive tillers and test weight at maturity accounted for $19 \%, 90 \%$ and $18 \%$ of total variation in grain yield of rice (Figure 4.11 ). 


\section{Regression between Nutrient Uptake and Grain Yield}

Regression equation obtained between N, P, K uptake and grain yield of rice at maturity accounted for $99 \%, 95 \%$ and $99 \%$ of total variation in grain yield of rice (Figure 4.12).

\section{Regression between Growth Parameters, Nutrient Uptake and Dry matter Production}

Regression equation obtained in the study revealed LAI, tillers $\mathrm{m}^{-2}, \mathrm{~N}, \mathrm{P}, \mathrm{K}$ uptake and straw yield of rice at maturity accounted for $68 \%, 88 \%, 98 \%, 94 \%$ and $99 \%$ of total variation in straw yield of rice (Figure 4.13, 4.14).

\section{REFERENCES}

1. Kumar, R.M., Surekha, K., Padmavathi, Ch., Rao, L.V.S., Latha, P.C., Prasad, M.S., Babu, V.R., Ramprasad, A.S., Rupela, O.P., Goud, P.V., Raman, P.M., Somashekar, N., Ravichandran, S., Singh, S.P and Viraktamath, B.C. 2009. Research experiences on System of Rice Intensification and future directions. Journal of Rice Research. 2 : 61-73.

2. Mohanty, S. 2013. Trends in global rice consumption. Rice Today: 44-45.

3. Ologunde, O.O. 1987. Institute of Agriculture research, ABU, Zaria. Samaru Miscellaneous Paper 118:4-6.

4. Singh, R.K and Namdeo, K.N. 2004. Effect of fertility levels and herbicides on growth, yield and nutrient uptake of directseeded rice (Oryza sativa). Indian Journal of Agronomy.49(1):34-36.

\section{APPENDICES}

Table 1: Correlation Studies in Rice between Grain Yields Versus Growth, Yield Attributes and N, P, K Uptake of Pooled Means

\begin{tabular}{|c|c|c|c|c|c|c|c|c|c|c|c|c|c|c|}
\hline Parameters & \begin{tabular}{|l|} 
Plant \\
Height
\end{tabular} & $\begin{array}{l}\text { Panicle } \\
\text { Length }\end{array}$ & $\begin{array}{c}\text { Tillers } \\
\mathbf{m}^{-2}\end{array}$ & LAI & \begin{tabular}{|c|} 
Test \\
Weight
\end{tabular} & \begin{tabular}{|c|} 
Filled \\
Grains
\end{tabular} & $\begin{array}{c}\text { Panicle } \\
\mathbf{m}^{-2}\end{array}$ & \begin{tabular}{|c|} 
Dry \\
Matter
\end{tabular} & \begin{tabular}{|c|}
$\mathbf{N}$ \\
Uptake
\end{tabular} & \begin{tabular}{|c|}
$\mathbf{P}$ \\
Uptake
\end{tabular} & \begin{tabular}{|c|} 
K \\
Uptake
\end{tabular} & $\begin{array}{c}\text { Sterility } \\
\%\end{array}$ & \begin{tabular}{|c|} 
Straw \\
Yield
\end{tabular} & $\begin{array}{l}\text { Grain } \\
\text { Yield }\end{array}$ \\
\hline Plant height & 1.000 & 0.853 & 0.154 & 0.545 & 0.867 & 0.879 & 0.021 & 0.155 & 0.263 & 0.283 & 0.168 & -0.854 & 0.154 & 0.188 \\
\hline Panicle length & & 1.000 & 0.283 & 0.566 & 0.982 & 0.609 & 0.201 & 0.408 & 0.515 & 0.467 & 0.421 & -0.875 & 0.416 & 0.438 \\
\hline Tillers $\mathbf{~ m}^{-2}$ & & & 1.000 & 0.866 & 0.294 & 0.210 & 0.963 & 0.940 & 0.917 & 0.951 & 0.933 & -0.089 & 0.929 & 0.934 \\
\hline LAI & & & & 1.000 & 0.574 & 0.564 & 0.811 & 0.831 & 0.853 & 0.890 & 0.831 & -0.429 & 0.820 & 0.839 \\
\hline Test weight & & & & & 1.000 & 0.604 & 0.198 & 0.402 & 0.507 & 0.481 & 0.415 & -0.848 & 0.408 & 0.434 \\
\hline Filled grains & & & & & & 1.000 & 0.098 & 0.139 & 0.219 & 0.281 & 0.146 & -0.746 & 0.130 & 0.163 \\
\hline Panicle $\mathbf{~ m}^{-2}$ & & & & & & & 1.000 & 0.958 & 0.925 & 0.946 & 0.954 & -0.020 & \begin{tabular}{|l|}
0.954 \\
\end{tabular} & 0.952 \\
\hline Dry matter & & & & & & & & 1.000 & 0.991 & 0.971 & 0.998 & -0.213 & 0.998 & 0.998 \\
\hline N uptake & & & & & & & & & 1.000 & 0.971 & 0.993 & -0.328 & 0.992 & 0.995 \\
\hline P uptake & & & & & & & & & & 1.000 & 0.969 & -0.267 & 0.967 & 0.974 \\
\hline K uptake & & & & & & & & & & & 1.000 & -0.228 & 0.999 & 0.999 \\
\hline Sterility \% & & & & & & & & & & & & 1.000 & -0.220 & -0.243 \\
\hline Straw yield & & & & & & & & & & & & & 1.000 & 0.998 \\
\hline Grain yield & & & & & & & & & & & & & & 1.000 \\
\hline
\end{tabular}



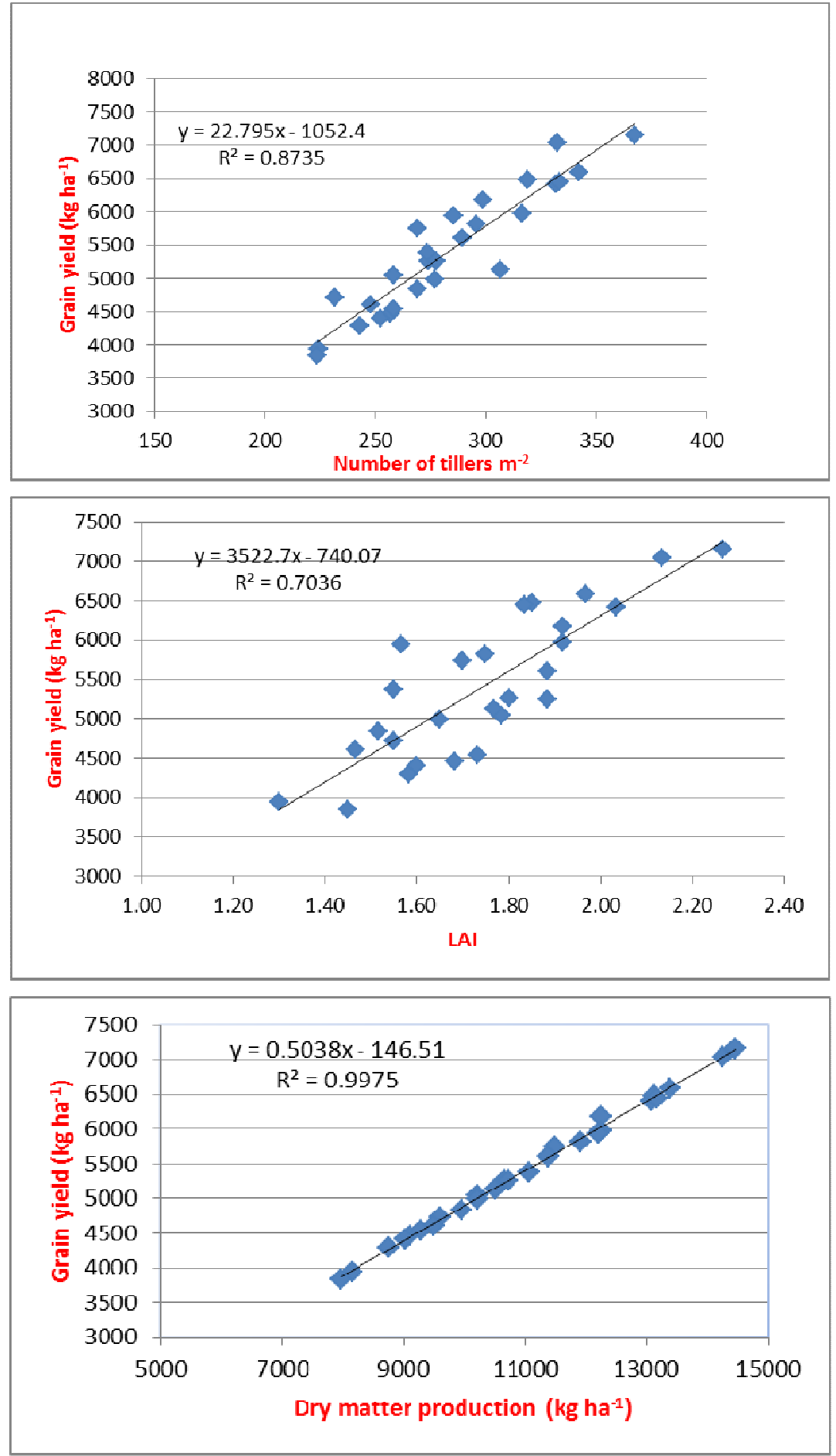

Figure 4.10: Regression of Grain Yield of Rice Versus Number of Tillers $\mathbf{~ m}^{-2}$, Leaf Area Index and Dry Matter Production of Pooled Means 

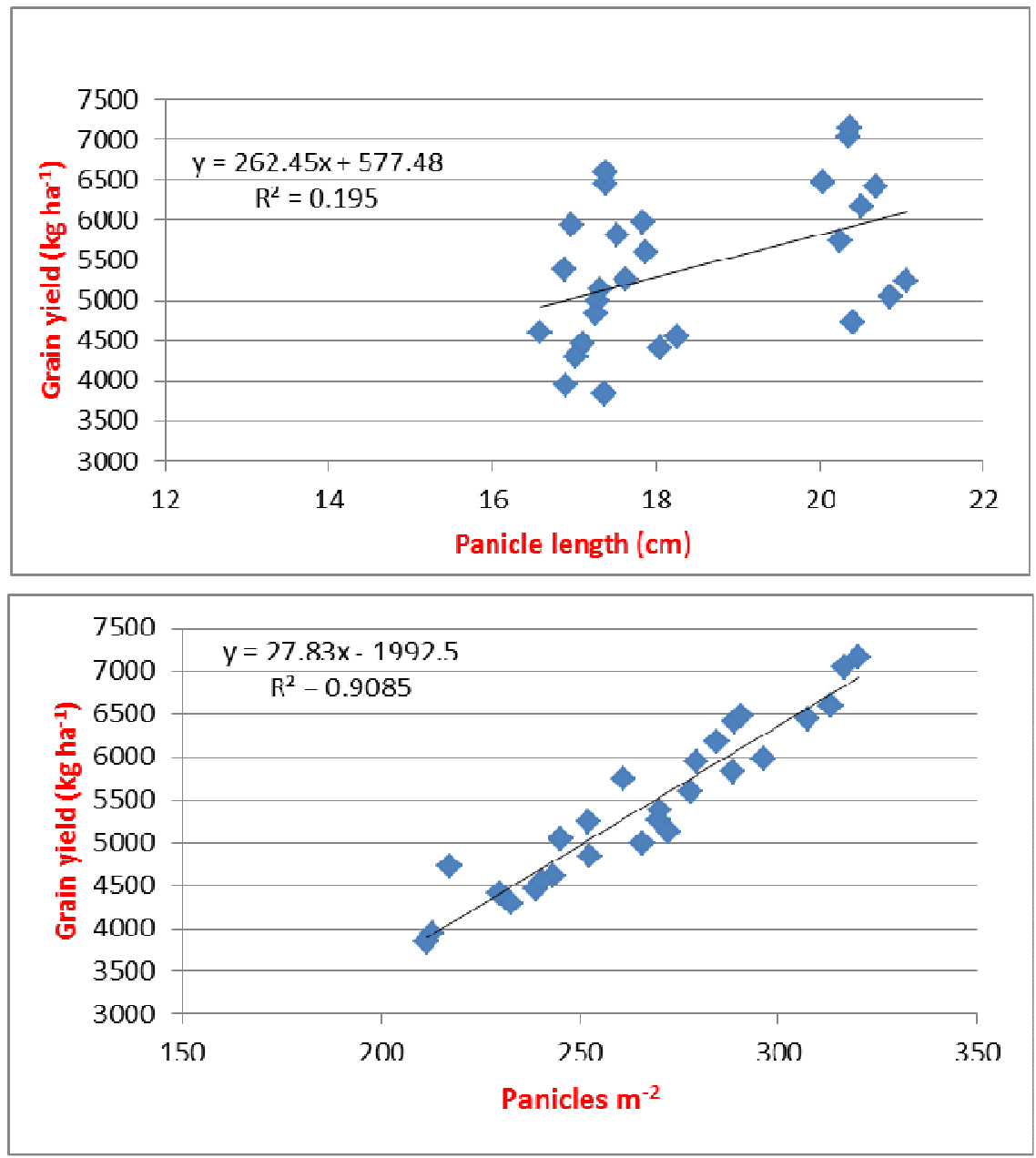

Figure 4.11: Regression of Grain Yield of Rice Versus Panicle Length, Panicles $\mathbf{m}^{-2}$, of Pooled Means

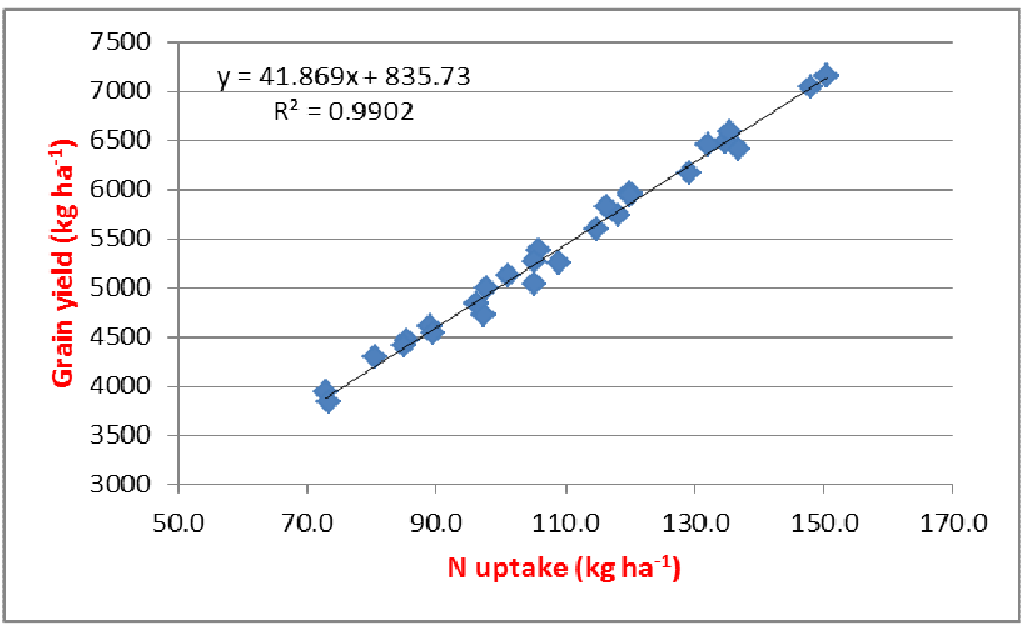



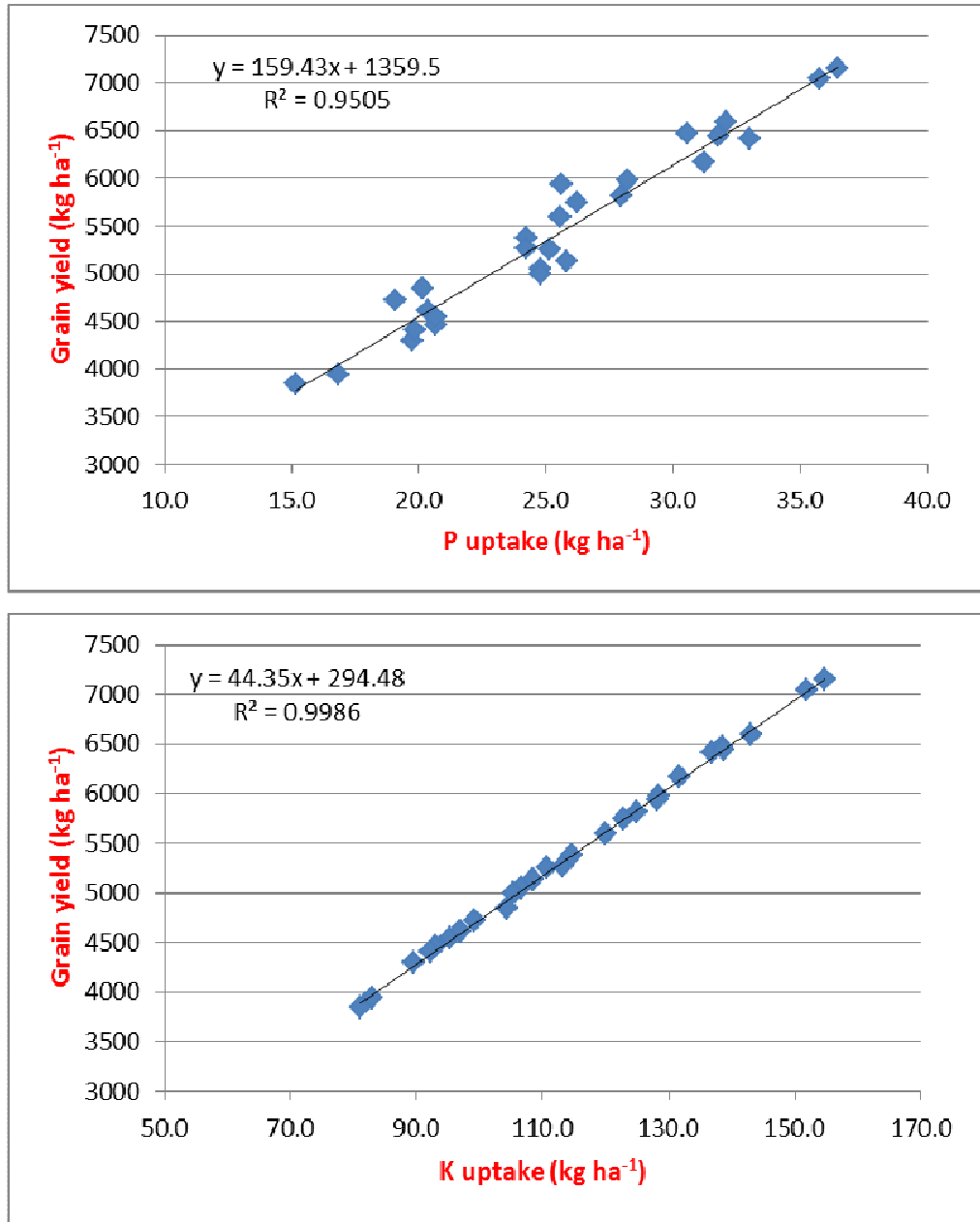

Figure 4.12: Regression of Grain Yield of Rice Versus N Uptake, P Uptake and K Uptake of Pooled Means

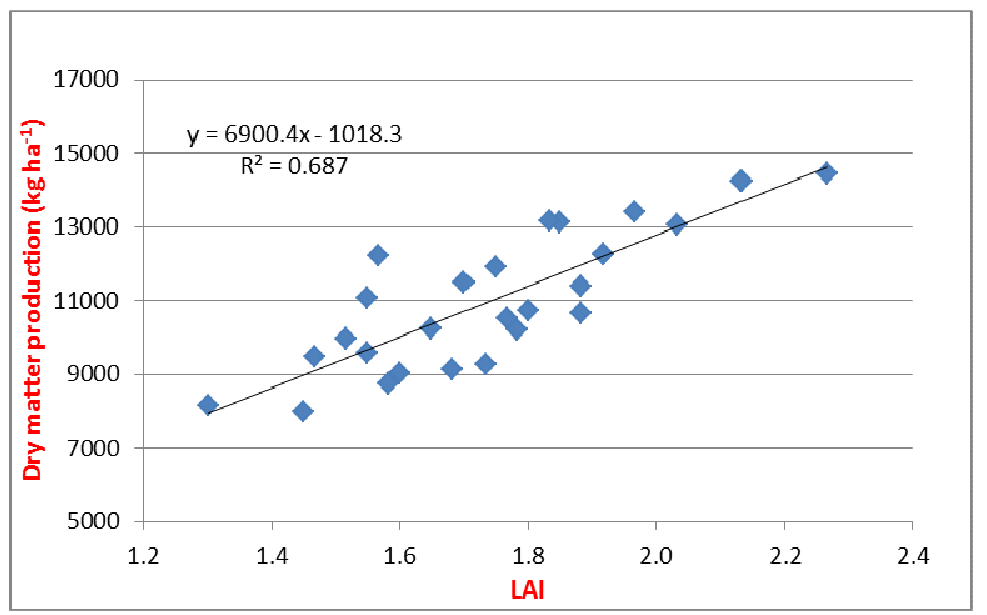




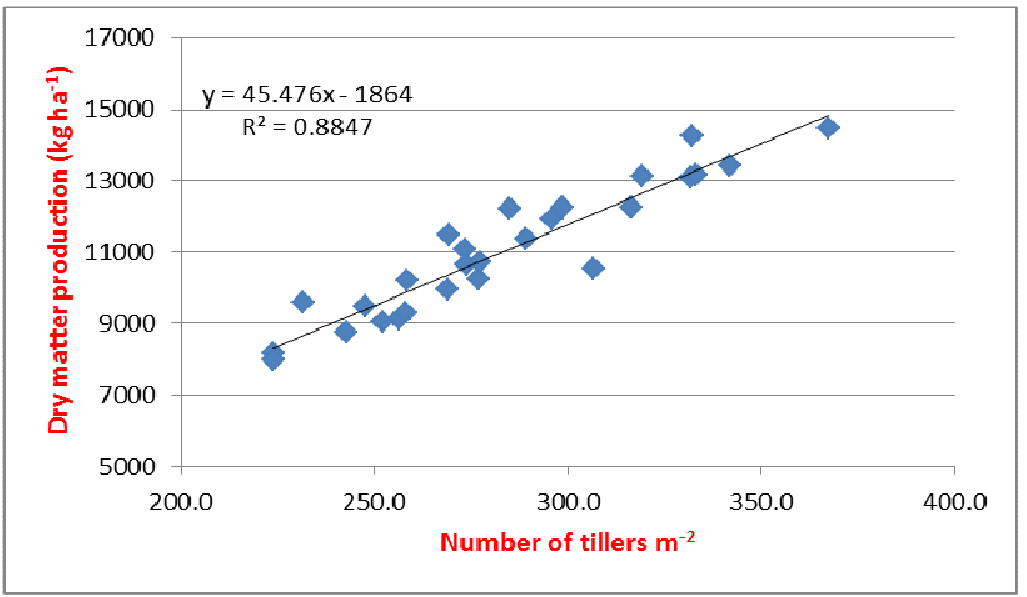

Figure 4.13: Regression of Dry Matter of Rice Versus Number of Tillers $\mathrm{m}^{-2}$ and Leaf Area Index of Pooled Means
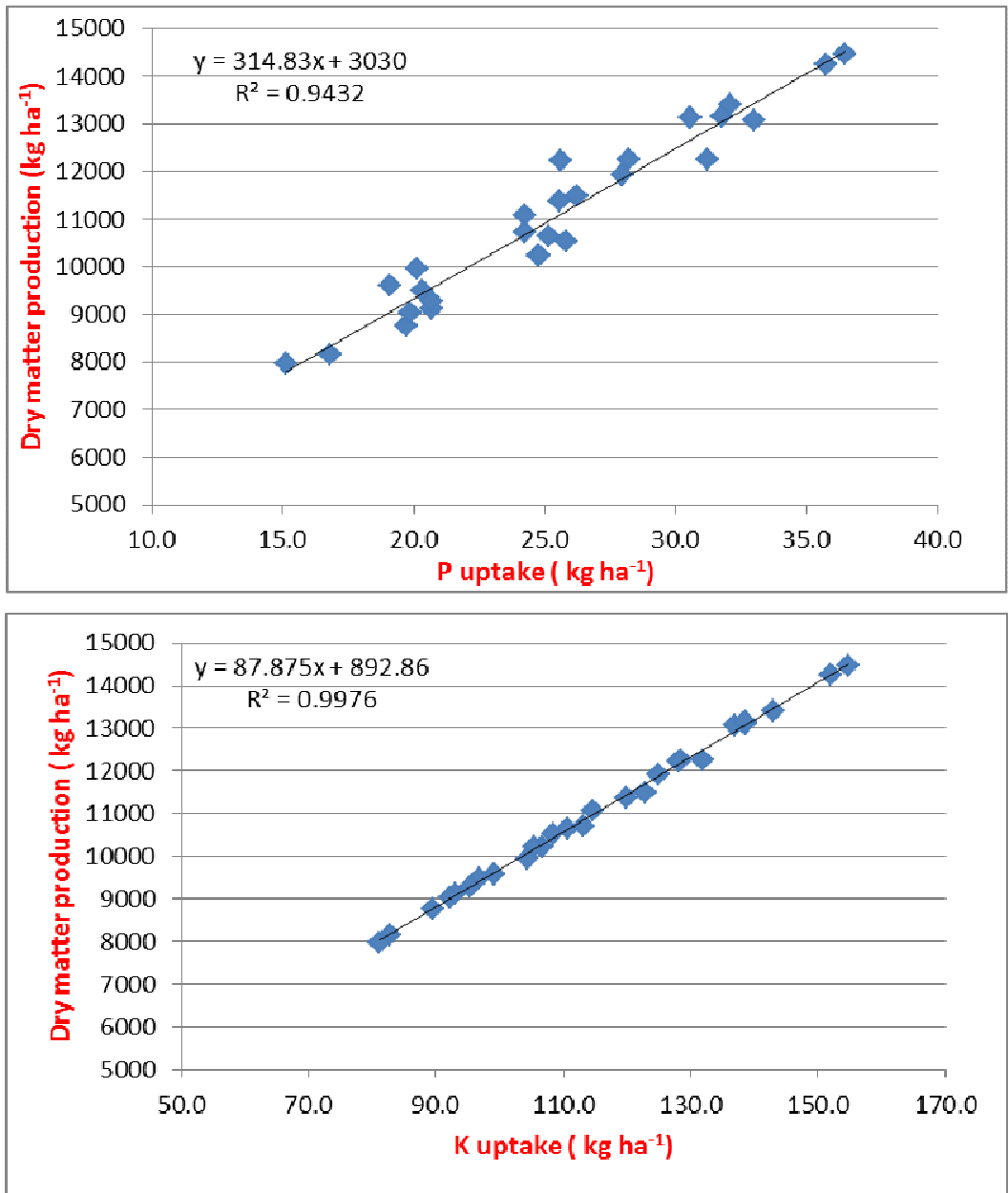

Figure 4.14: Regression of Dry Matter of Rice Versus N Uptake, P Uptake and K Uptake of Pooled Means 